Article

\title{
An Investigation into the Limitations of Low Temperature District Heating on Traditional Tenement Buildings in Scotland
}

\author{
Michael-Allan Millar *, Neil Burnside ${ }^{\circledR}$ and Zhibin Yu \\ James Watt School of Engineering, Systems, Power and Energy division, University of Glasgow, \\ Glasgow G12 8QQ, UK \\ * Correspondence: michael.millar@glasgow.ac.uk; Tel.: +44-(0)-141-330-2000
}

Received: 31 May 2019; Accepted: 4 July 2019; Published: 6 July 2019

check for updates

\begin{abstract}
Domestic heating accounts for $64 \%$ of domestic energy usage in the UK, yet there are currently very few viable options for low carbon residential heating. The government's carbon plan commits to improving the uptake of district heating connections in new build dwellings, but the greatest carbon saving can be made through targeting traditional housing stock. This paper aims to quantify the potential carbon and energy savings that can be made by connecting a traditional tenement building to a district heating scheme. The study uses a transient system simulation tool (TRNSYS) model to simulate the radiator system in a tenement block and shows that a significant benefit can be achieved by reducing the supply temperature; however, the minimum supply temperature is drastically limited by the building condition. Therefore, the study also critically compares the benefits of a lower supply temperature against minor refurbishments. It was found that improving building conditions alone could offer a 30\% reduction in space heating energy consumption, while building improvements and integration of a river source heat pump could offer almost a $70 \%$ reduction. It is the recommendation of this study that a dwelling be improved as much as economically possible to achieve the greatest carbon and energetic savings.
\end{abstract}

Keywords: district heating; residential; domestic; Scotland; TRNSYS; retrofit

\section{Introduction}

Residential energy use has changed significantly from the 19th century until now, moving from solid fuel combustion (e.g., coal/wood stoves) to a predominantly gas heating market, which totals $64 \%$ of domestic energy usage in the UK in 2017 [1]. The Scottish government has set ambitious targets to provide $11 \%$ of non-electrical heat demand by renewable sources by 2020 , and for $35 \%$ of domestic heat to be provided by renewable sources by 2032 [2]. The government also aims for all Scottish homes to have an energy performance certificate (EPC) of at least band C by 2040, where "technically feasible and cost effective" [2]. In Scotland, the greatest number of dwellings by type is tenement flats, and more than $74 \%$ of housing stock was built pre-1982, as shown in Figure 1 [3]. This suggests, in order to achieve Scottish government targets, the greatest focus must be on modernizing existing housing stock, rather than new housing. 


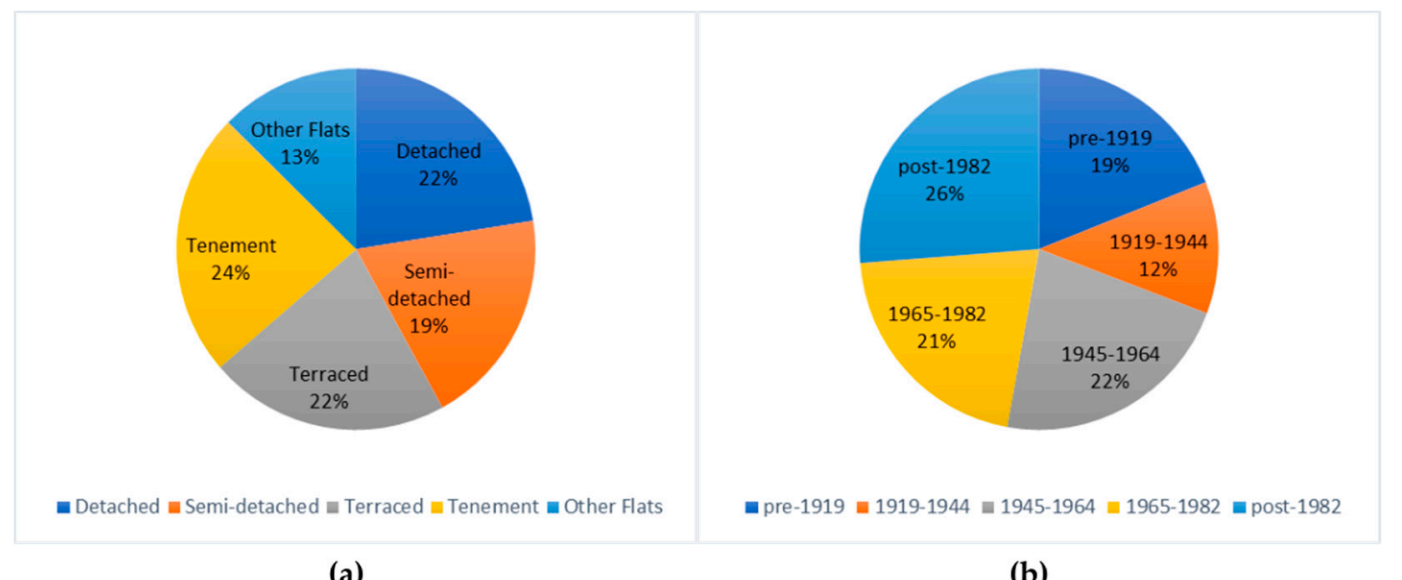

(a)

(b)

Figure 1. Breakdown of Scottish dwelling type by (a) number and (b) year built, in 2017 [3].

Limited work has been completed to the assess the suitability of existing residential buildings to connect to a district heating network (DHN); examples shown in [4-11]. Brand and Svendsen [6] discuss the necessary upgrades to existing stock in order to integrate a low temperature district heating network (LTDHN). They show that for a typical single-family, Danish house from the 1970s, small refurbishment can allow the district heating supply temperature to drop from $78^{\circ} \mathrm{C}$ to $67^{\circ} \mathrm{C}$, and below $60{ }^{\circ} \mathrm{C}$ for $98 \%$ of the year. This study uses a home already connected to a DHN and compares the energy demand between the traditional DHN and a LTDHN. The paper shows promising results with minor investment. However, while the paper acknowledges the need for water disinfection for supply temperatures below $60^{\circ} \mathrm{C}$, it is difficult to know how this will influence the overall efficiency, carbon savings or cost. Østergaard and Svendsen [8] provide an investigation into the use of LTDHNs from the 1930s in single family houses, a similar study to Brand and Svendsen [6]. This study considers the influence of replacing critical radiators, and found that while $50 \%$ of the case studies could be converted to LTDH with minor renovations, $50 \%$ would require substantial work. This work is not directly transferable to the UK due to different building styles and weather patterns, but does, however, show the first steps in considering options for existing housing stock.

Wang and Holmberg [11] discuss retrofitting Swedish multi-family buildings from 1965-1975 with low temperature heating and a heat recovery ventilation system (FTX ventilation). While this discussion is limited, it does show that savings could be made on space heating-albeit with significant renovations, which would likely be out-weighed by the significant cost of improving/installing the DHN substation, installing the ventilation system, and improving the air tightness, as is recommended by the paper.

Burzynski et al. [12] provide a valuable insight to space heating and domestic hot water demands from newer tenement flats (built 2007-2010) connected to district heating schemes in the UK. The study makes use of metered data provided by one of the big six energy providers, Scottish and Southern Energy (SSE), to present floor area normalized energy usages for space heating and domestic hot water. A standard heat interface unit in a UK dwelling with district heating will only measure the total heat supplied to the property and will give no indication of the split between space heating or hot water. To find this split, Burzynski et al. [12] first applied a regression analysis to estimate a base temperature for heating degree days. The heat supplied on the calculated non-heating days was then assumed to be only for hot water, giving a baseline usage which can be subtracted from the total heat for the rest of the year to differentiate between space heating and hot water heating. The results of Burzynski et al. [12] do not correlate with SAP 2005 or SAP 2009; this could be due to an underestimation of heating in the methodology of the authors, which differs from the SAP method for estimating energy consumption, however this performance gap has been well documented elsewhere [13-17]. This is a significant piece of work for the UK district heating market, but will have limited applications to a significant majority of housing, which does not follow the Building Regulations part L or Section 6 (Scotland). The flats in 
this study have a district heating supply, but it is unclear if this has been from build or retrofitted later (although likely from build, due to the age of the dwellings).

Ovchinnikov et al. [18] give a comparative review of low temperature heating systems with a focus on the practicalities of the Russian building sector. In this paper, the authors discuss the merits of being able to use smaller radiators with a higher supply temperature, before going on to discuss the low energy efficiency of this approach. The authors mention the priority of addressing consumer awareness of energy usage. The authors discuss the challenges and obstruction of $4 \mathrm{G}$ heat networks by obsolete $3 \mathrm{G}$ networks. This is an interesting insight into the contrast between the challenges of heat network integration in the UK and abroad. While the UK is installing new networks, many other countries must consider how to best improve existing networks. The paper concludes that low temperature heating can be used in existing Russian housing, however, significant energy efficiency can only be achieved with vast refurbishment and building improvement. In a further paper, using an IDA Indoor Climate and Energy (IDA ICE) tool, Ovchinnikov et al. [19] provide a dynamic model and assessment of Russian building regulations and the feasibility of low-temperature heating for residential buildings. The study investigates four hydronic space-heating configurations with either a high temperature supply $\left(75^{\circ} \mathrm{C}\right)$ or low temperature supply $\left(45^{\circ} \mathrm{C}\right)$. The paper concluded that a heat pump supply could offer good energy savings for many of the case studies and operating conditions.

Peeters et al. [20] assess heating control in residential buildings for a Belgian case study. The study describes the current heating practice in Flanders by first summarizing previous housing surveys and boiler conditions. This data is then used in a TRNSYS model to evaluate the efficiency of gas boiler systems with varying levels of insulation. The case study models a terraced house with a multizone thermostat and night set back and concludes that optimal efficiency can be achieved when a flexible heating design is used, which is able to cope with large variations in heating load. A very similar study was performed by Liao et al. [21] in a UK context, however this focused on non-domestic users and no new information is provided for UK domestic dwellings.

On considering the current state of the literature, we present in this study the transient system simulation tool (TRNSYS) models, where we consider the necessary building improvements for a typical Scottish tenement flat to be connected to a district heating network or a low temperature district heating network. Lowering the supply temperature of a heating system requires careful consideration to the building condition. Therefore, we first consider and discuss the minimum supply temperature achievable to maintain a reasonable thermal comfort level at different levels of building renovation. The calculated minimum supply temperature is then used as the set point for the LTDH river source heat pump loop. A parametric analysis is provided, showing the energy and carbon savings achievable from district heating in each case study. The aims of this study are to:

1. Through dynamic computational modelling, assess the minimum radiator supply temperature which can maintain a reasonable thermal comfort in a Scottish/UK domestic dwelling, under various building conditions.

2. Assess the potential energy and therefore carbon reduction of implementing the minimum chosen supply temperature.

3. Qualitatively assess the feasibility of a river source heat pump to meet the demand of domestic heating.

The modelling tool chosen is TRNSYS. TRNSYS is a simulation environment which can be used to extensively model HVAC and building systems, amongst other things. The user can select from a range of pre-installed "types", which computationally represent physical components. At each time-step, the TRNSYS kernel feeds inputs to the different types that produce the outputs. The process is described in further detail in the TRNSYS documentation [22,23].

\section{Methodology}

The methodology is as follows: 
1. Define the case study.

2. Develop a building model.

3. Assess minimum supply temperature for each case using a TRNSYS model.

4. Use chosen supply temperature to assess operability and control operation of river source heat pump.

5. Assess energetic and carbon benefits.

\subsection{Case Studies}

There are many choices available to improve the energy efficiency of a dwelling. For this study, two of the most common home improvements were chosen for consideration-double glazing and wall insulation. The case studies are summarized in Table 1.

Table 1. Summary of case studies.

\begin{tabular}{ccccc}
\hline Case Number & Single Glazing & Double Glazing & Insulation & No Insulation \\
\hline 1 & $X$ & & & $X$ \\
2 & $X$ & $X$ & $X$ \\
3 & $X$ & $X$ & \\
4 & & $X$ & $X$ & \\
\hline
\end{tabular}

The chosen case study is a traditional sandstone tenement flat, a common building type in Scotland. Tenement walls are typically solid wall, with no cavity. This makes insulation difficult, as it must be either internal or external. External insulation is not a recommended choice as it will inevitably change the appearance of the building. Internal insulation is possible, however, it will remove a small amount of internal space. Internal insulation is the only feasible option and therefore is the only one considered here. The supply temperature is varied from $60-100{ }^{\circ} \mathrm{C}$ to mimic a broad range of typical DHN supply temperatures.

\subsection{Building Modelling}

To be of any significance, the building choice must be typical tenement housing stock; unfortunately, due to the age of the buildings, accurate and updated plans are not publicly available. The building layout was chosen from available plans of a typical tenement and is therefore not specific to any site (however, many tenement buildings will follow this structure). As the plans are not updated, they do not include any consideration to building modifications or renovations; however, as the modelled dwellings are less than $150 \mathrm{~m}^{2}$ floor area, they can each be modelled as a single thermal zone. This makes any error due to un-accounted for renovations likely to be insignificant.

The building geometry was produced from building plans of a typical 20th century Glasgow tenements, shown in Figure 2. The geometry was created in Sketchup (previously Google Sketchup), shown in Figure 3, and TRNSYS3d. TNSYS3d is a Sketchup extension which allows the construction types to be defined in Sketchup (e.g., external wall, window, roof etc.) and then exported as a *.idf file, which is then imported to TRNBuild, where the thermal properties of the building can be implemented. TRNBuild produces a ${ }^{*}$.b18 file which can then be used in the TRNSYS simulation studio with Type56 multizone modelling component. 


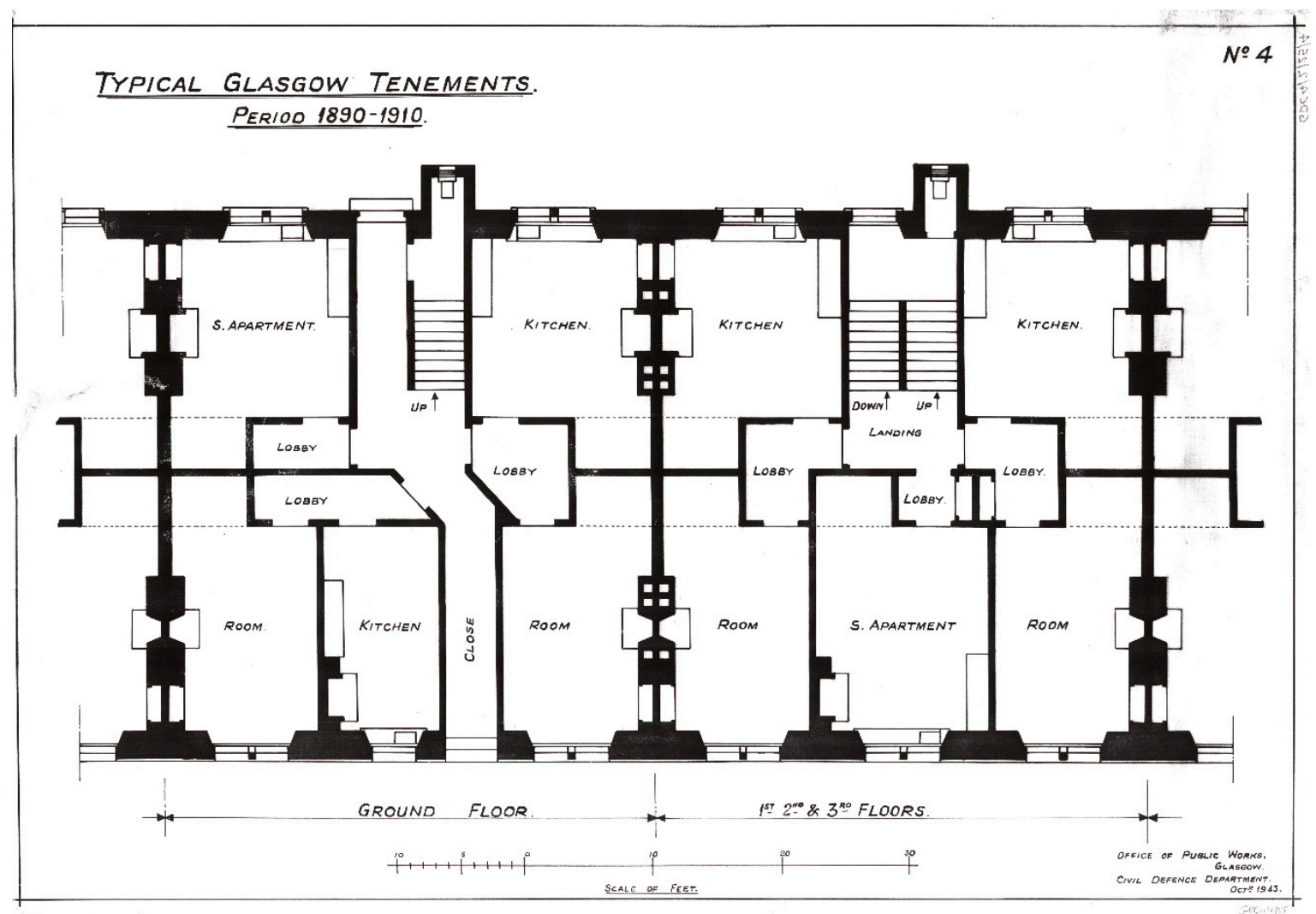

Figure 2. Typical Glasgow tenement plans. Reproduced with permission from Glasgow City Archives.

(a)

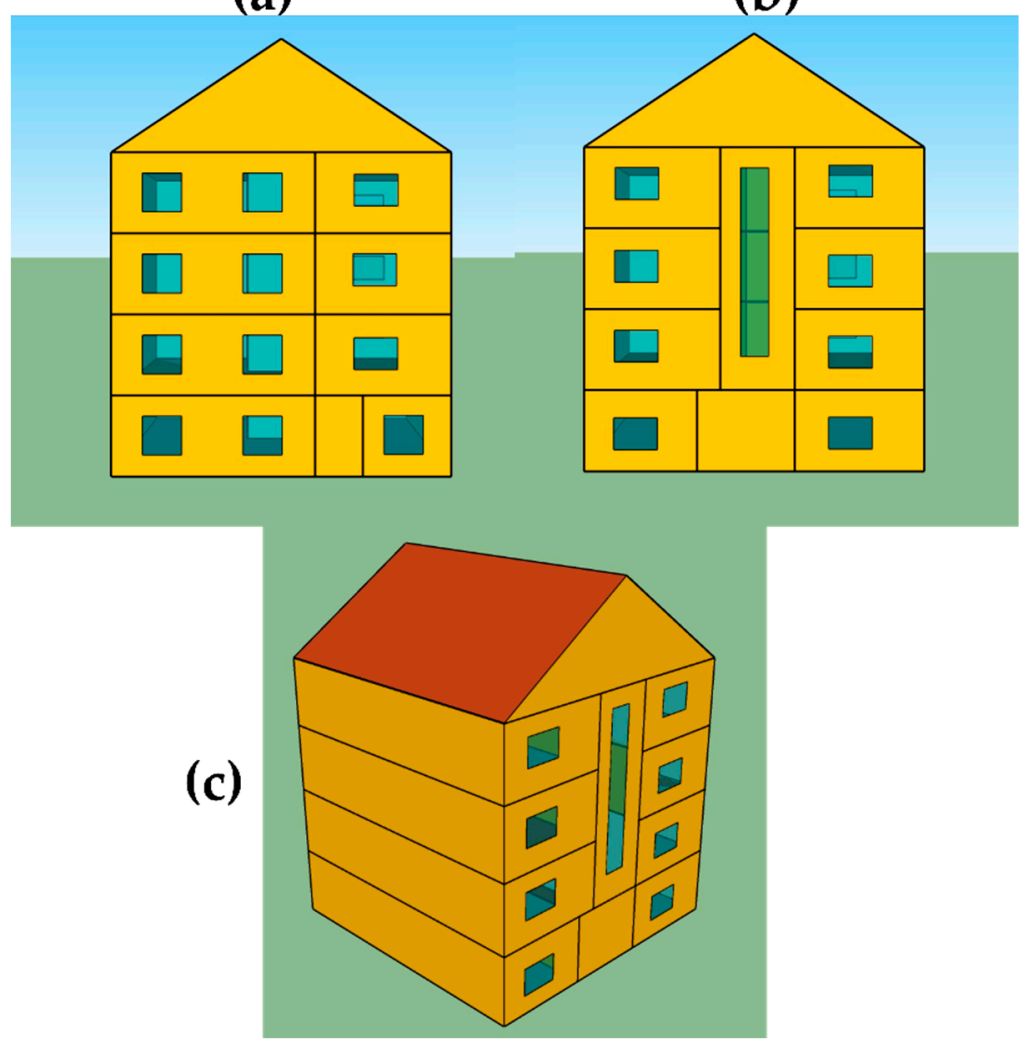

Figure 3. (a) Front, (b) back, and (c) isometric view of modelled tenement. 
The single close of flats contains eight dwellings. Only one close is shown, although it is typical for tenement blocks to have 20 to 30 closes.

The initial TRNBuild construction types chosen are shown in Table 2.

Table 2. Initial heat transfer co-efficient of TRNBuild constructions.

\begin{tabular}{ccc}
\hline Construction Type & Materials & U Value $\left(\mathbf{W} / \mathbf{m}^{\mathbf{2}} \mathbf{K}\right)$ \\
\hline EXT_WALL & $\begin{array}{c}\text { Plasterboard } \\
\text { Sandstone } \\
\text { Plasterboard } \\
\text { Slate }\end{array}$ & 1.0 \\
EXT_ROOF & $\begin{array}{c}\text { Plasterboard } \\
\text { Brick }\end{array}$ & 2.5 \\
ADJ_WALL & OAK & 2.4 \\
ADJ_CEILING & & 2.4 \\
GROUND_FLOOR & & 0.78 \\
\hline
\end{tabular}

Data is not available to consider how many properties exist with original fixtures and structures, however, the considered modifications are shown in Table 3 with thermal conductivity (U) values [24].

Table 3. Heat Transfer co-efficient for building materials.

\begin{tabular}{cc}
\hline Building Component. & Thermal Conductivity $\left(\mathbf{W} / \mathbf{m}^{\mathbf{2}} \mathbf{K}\right)$ \\
\hline Single-glazed wooden windows & 5.8 \\
Double-glazed PVC windows & 1.2 \\
Solid wall—no Insulation & 1.0 \\
Solid wall—insulated & 0.18 \\
\hline
\end{tabular}

It is assumed that the roof has been replaced since initial construction, however, since this is not part of the upper dwellings, it is not considered with renovations.

\subsection{Minimum Supply Temperature}

For each dwelling, there is a minimum supply temperature of space heating, dependent on the dwelling's ability to retain heat and the radiator capacity. Using TRNSYS, this is determined for each building construction case, as shown in Table 1. These temperatures are then used as a basis for the following sections. The TRNSYS model used to determine the minimum supply temperature is shown in Figures 4 and 5. The expanded macro shown in Figure 5 is the same for all "Flat X" macros. Radiators in the UK are typically designed for an $82^{\circ} \mathrm{C}$ supply and $71{ }^{\circ} \mathrm{C}$ return temperature and are supplied by gas boilers. Energy and cost savings are therefore calculated against this as the base case [25]. 


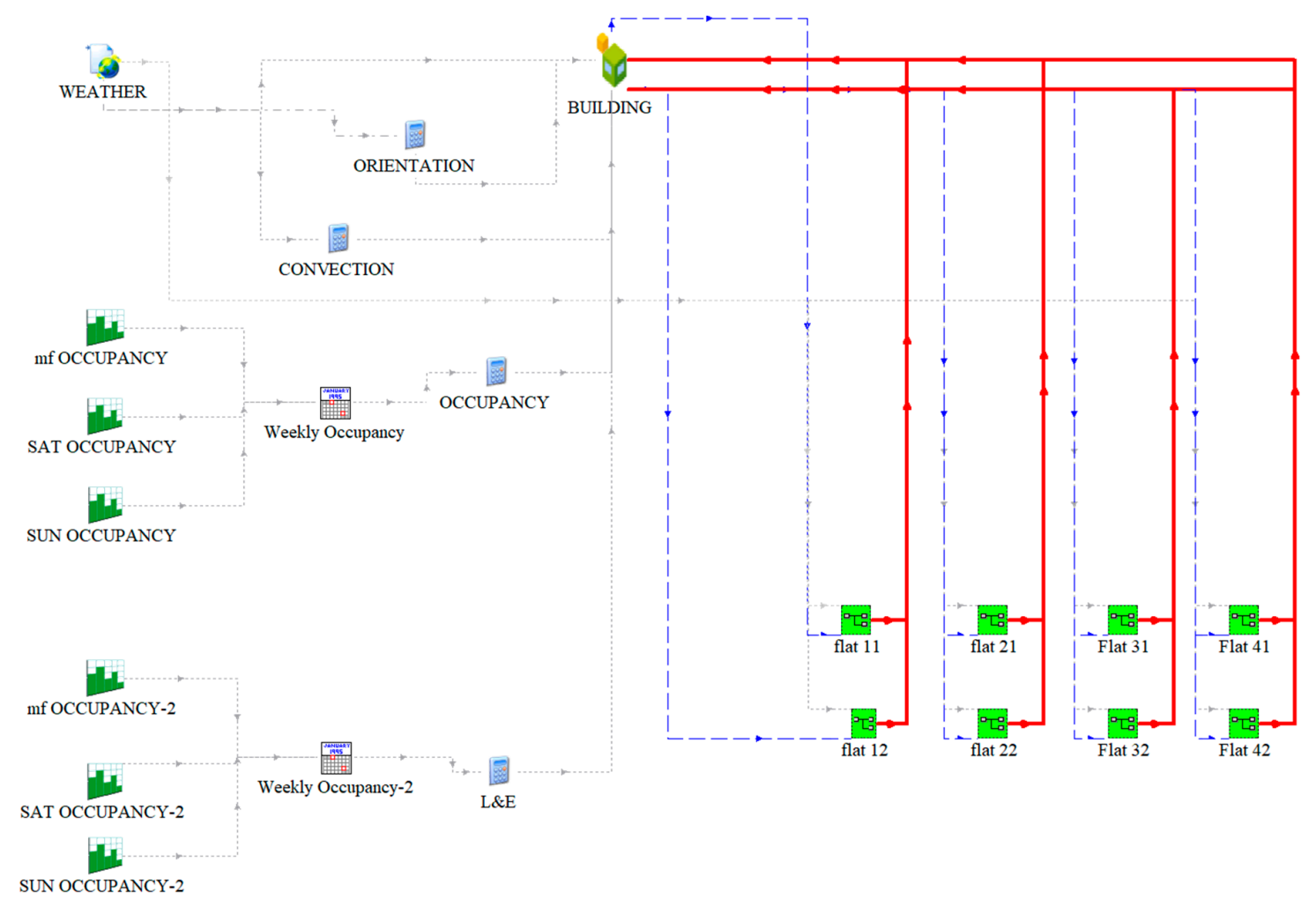

Figure 4. TRNSYS Simulation Model. Blue lines show cold streams, red shows hot streams and grey shows auxiliary streams (occupancy schedules, control signals etc.).

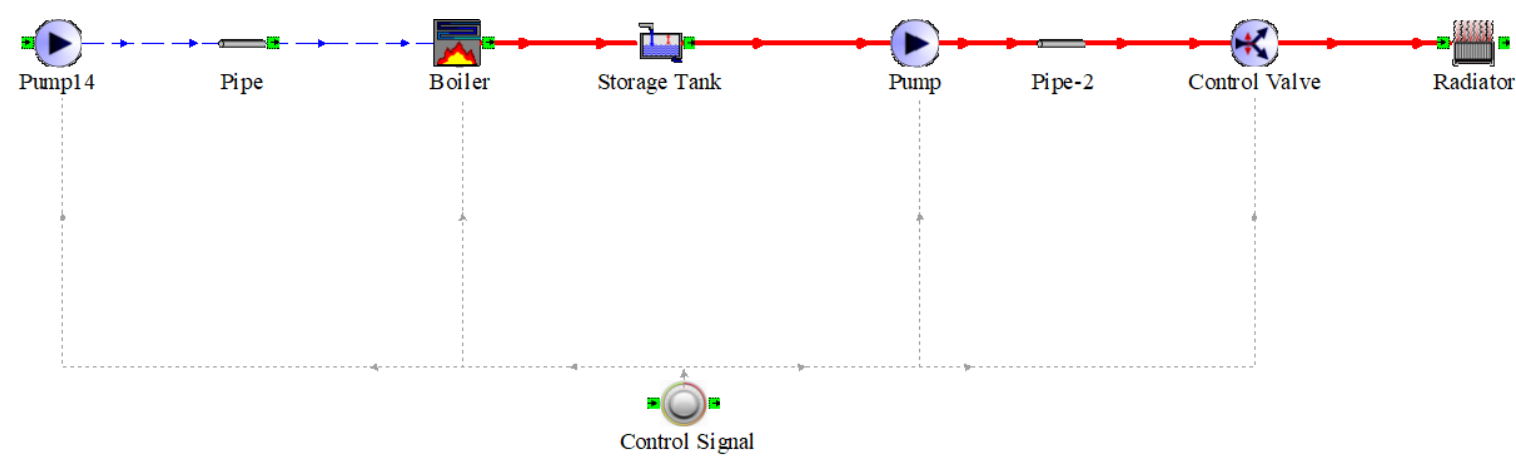

Figure 5. Expanded TRNSYS Model macro.

The air set point temperature of the dwellings is chosen as $20^{\circ} \mathrm{C}$ during occupied periods, based on a generic occupancy schedule $[6,26]$. To maintain the set point temperature, the radiators must balance the thermal losses from each dwelling. The energy balance used in the building model is given in Equations (1)-(3) [27].

$$
\dot{Q}_{\text {ConGain }}=\dot{Q}_{\text {surface }}+\dot{Q}_{\text {infil }}+\dot{Q}_{\text {vent }}+\dot{Q}_{I C G}+\dot{Q}_{C A G}+\dot{Q}_{\text {Solwin }}+\dot{Q}_{\text {solshade }}
$$

where $\dot{Q}_{\text {ConGain }}$ is the air node convective heat gain, $\dot{Q}_{\text {surface }}$ is the convective surface gains, $\dot{Q}_{\text {infil }}$ is the infiltration gains, $\dot{Q}_{\text {vent }}$ is the ventilation gains, $\dot{Q}_{I C G}$ is the internal convective gains, $\dot{Q}_{C A G}$ is the convective air gains from other thermal zones, $\dot{Q}_{\text {Solwin }}$ the convective solar gains from external windows and $\dot{Q}_{\text {solshade }}$ is the portion of convective gains from absorbed solar radiation on shading devices. There is no mechanical ventilation and so:

$$
\dot{Q}_{\text {vent }}=0
$$


It is impossible to accurately determine air exchange between flats without further study, so it is assumed to be negligible for the purpose of this investigation. Therefore

$$
\dot{Q}_{C A G}=0
$$

The heat addition from infiltration is given as

$$
\dot{Q}_{\text {infil }}=\dot{V} \rho c_{p}\left(T_{\text {outside air }}-T_{\text {inside air }}\right)
$$

where $\dot{V}$ is the volumetric flow rate of air, $\rho$ the air density, $\mathrm{c}_{\mathrm{p}}$ the specific heat capacity and $\mathrm{T}$ the temperatures of the outside and inside air.

The radiative fraction calculations are complex and explained in detail elsewhere [27-29].

\subsection{Water Source Heat Pump Design}

The heat supply technology chosen is a river source heat pump, due to Glasgow's large resource of river water. This is designed to operate by extracting $3{ }^{\circ} \mathrm{C}$ from the supply river water and deliver it to the main water. Although there are examples of water source heat pumps being able to condition water streams to $80^{\circ} \mathrm{C}$, WSHPs are typically only rated by manufacturers to $60 / 65^{\circ} \mathrm{C}$. For this reason, the heat pump is designed to condition the load stream to $60^{\circ} \mathrm{C}$. The load stream is then supplied with auxiliary heat from a gas boiler until it reaches the design supply temperature. No consideration is given to parasitic electrical load in the COP calculations (e.g., the electricity required to pump water to the heat pump). Figure 6 shows the adjusted TRNSYS model.

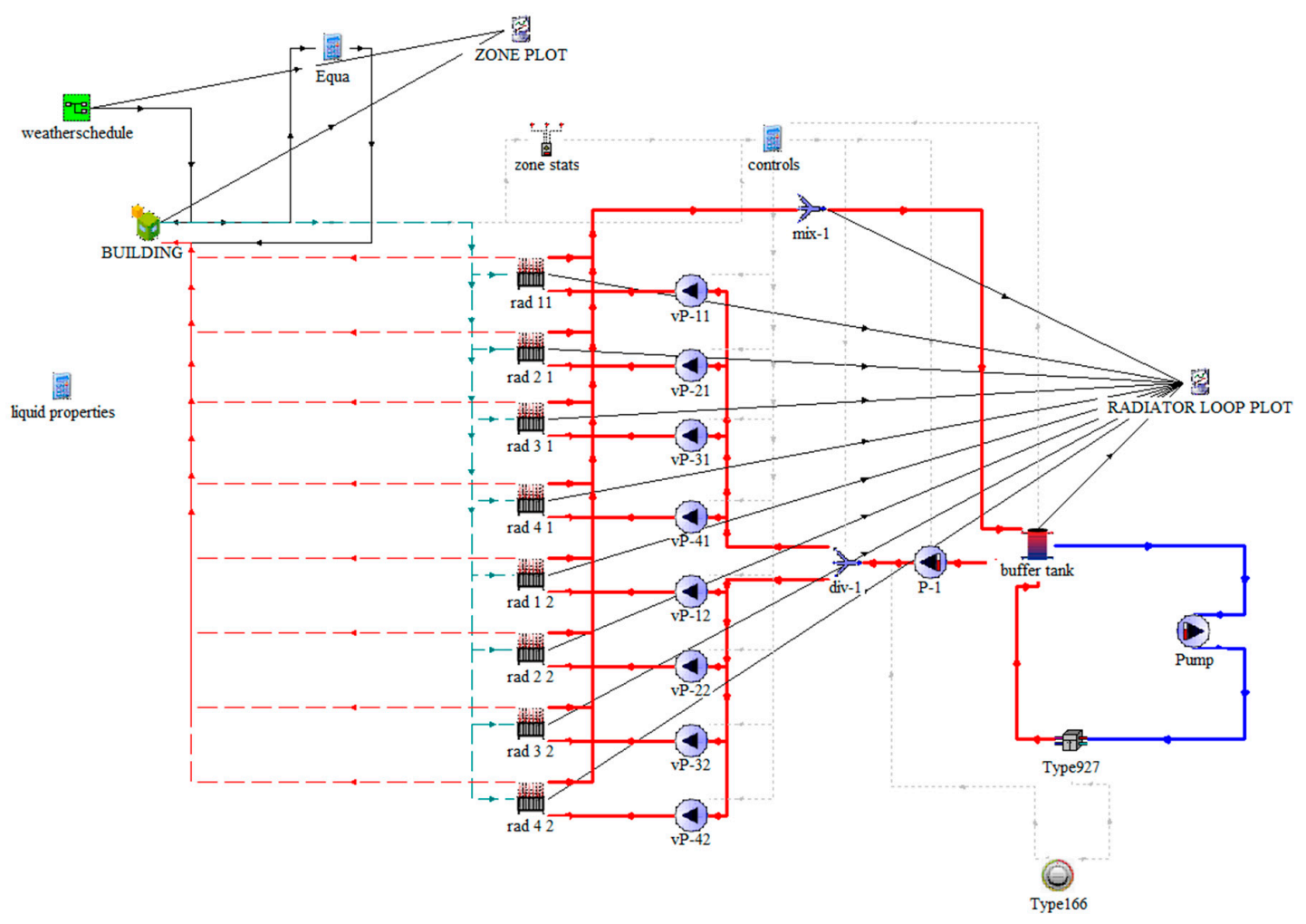

Figure 6. TRNSYS model used for heat pump supply modelling.

Figures 7 and 8 show the daily average temperature and cross-sectional flow of the River Clyde at Daldowie (NS 67154 61642). There are currently no limitations imposed by the local authority on heat extraction, however, for operational reasons the heat pump is controlled to extract $3^{\circ} \mathrm{C}$ from the abstracted river flow and to switch off when the return flow to the river falls below $2{ }^{\circ} \mathrm{C}$. This sets a 
lower operating temperature of $5{ }^{\circ} \mathrm{C}$ on the abstracted river stream. When the heat pump is off, the radiator loop is conditioned to the set point by the gas boilers only. A simple proportional controller is used for the purposes of this study, but a more sophisticated control system could make it possible to store heat prior to the river dropping below $5{ }^{\circ} \mathrm{C}$.

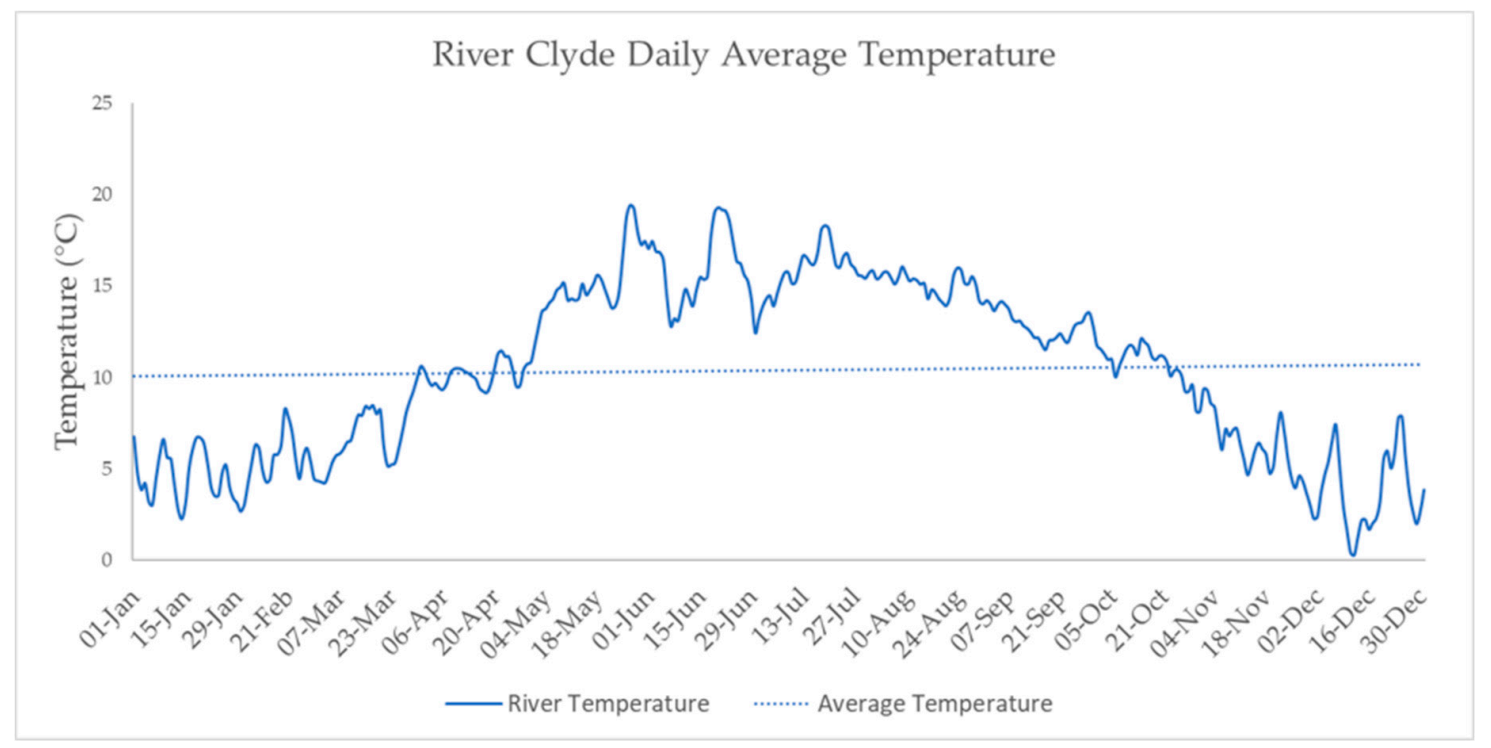

Figure 7. Average daily River Clyde water temperature at Daldowie for 2017.

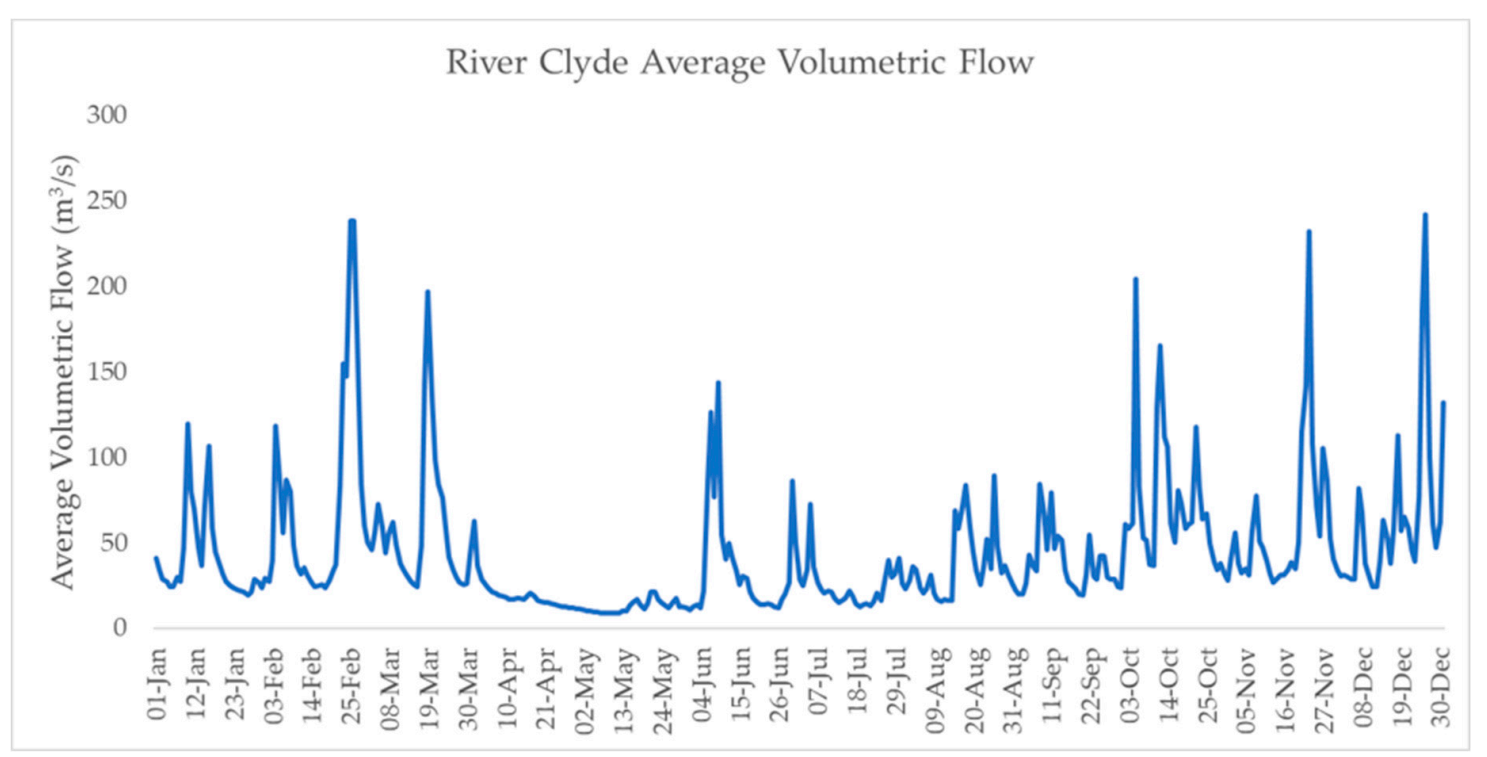

Figure 8. River Clyde average daily volumetric flow at Daldowie for 2017.

\subsection{Radiator Loop}

The radiator circuit is a closed loop feed, going from a small buffer tank to the radiator system and then back to the tank. The intermediate components shown in Figure 5 control the supply rates and pressure in the loop. Each dwelling is designed with $5 \mathrm{~kW}$ of radiator capacity, which is typical of this dwelling type. From radiator sizing guidelines, this is undersized for the property-a common problem in UK housing. 


\subsection{Carbon Benefits}

A standard carbon calculation is used to determine the carbon footprint of two energy systems. The first system is where the entire thermal load is met by a gas boiler. It is assumed that a condensing boiler is used with an efficiency of $90 \%$ [30,31]. The second system uses the heat pump to initially heat the water to $60^{\circ} \mathrm{C}$, and then uses a gas boiler to reach the set point temperature.

\section{Results}

\subsection{Minimum Supply Temperature}

Table 4 shows the average percentage of timesteps where the heating system could not maintain the set point temperature. Figures 9-12 show the percentage of timesteps where the zone air temperature fell below $19^{\circ} \mathrm{C}$. Figure 13 shows the heating power across the sample year.

Table 4. Average percent of timesteps below $19^{\circ} \mathrm{C}$ across all dwellings.

\begin{tabular}{ccccc}
\hline \multicolumn{5}{c}{ Average \% of Timesteps below $\mathbf{1 9}{ }^{\circ} \mathbf{C}$} \\
\hline \multirow{2}{*}{ Supply Temperature $\left({ }^{\circ} \mathbf{C}\right)$} & \multicolumn{4}{c}{ Case } \\
\cline { 2 - 5 } & Case 1 & Case 2 & Case 3 & Case 4 \\
\hline 60 & 88.7 & 49.0 & 37.0 & 30.7 \\
65 & 81.7 & 39.7 & 27.0 & 20.9 \\
70 & 72.9 & 30.6 & 18.2 & 13.0 \\
75 & 61.0 & 22.0 & 11.3 & 7.4 \\
80 & 47.7 & 14.9 & 6.5 & 3.8 \\
85 & 34.7 & 9.2 & 3.2 & 1.7 \\
90 & 22.4 & 5.2 & 1.3 & 0.5 \\
95 & 12.9 & 2.8 & 0.4 & 0.1 \\
100 & 7.6 & 1.4 & 0.1 & 0.0 \\
\hline
\end{tabular}

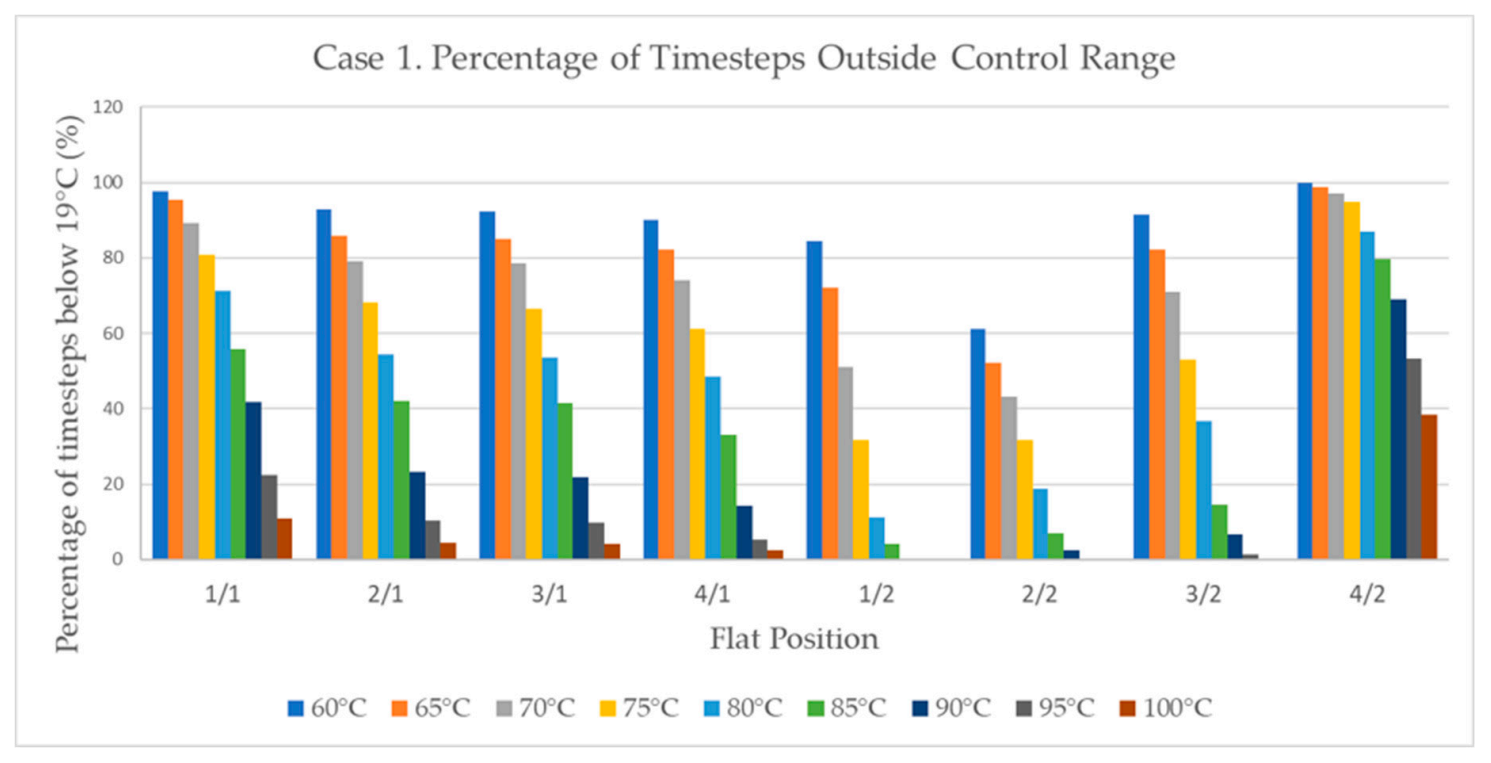

Figure 9. Case 1: no insulation and single glazing. 


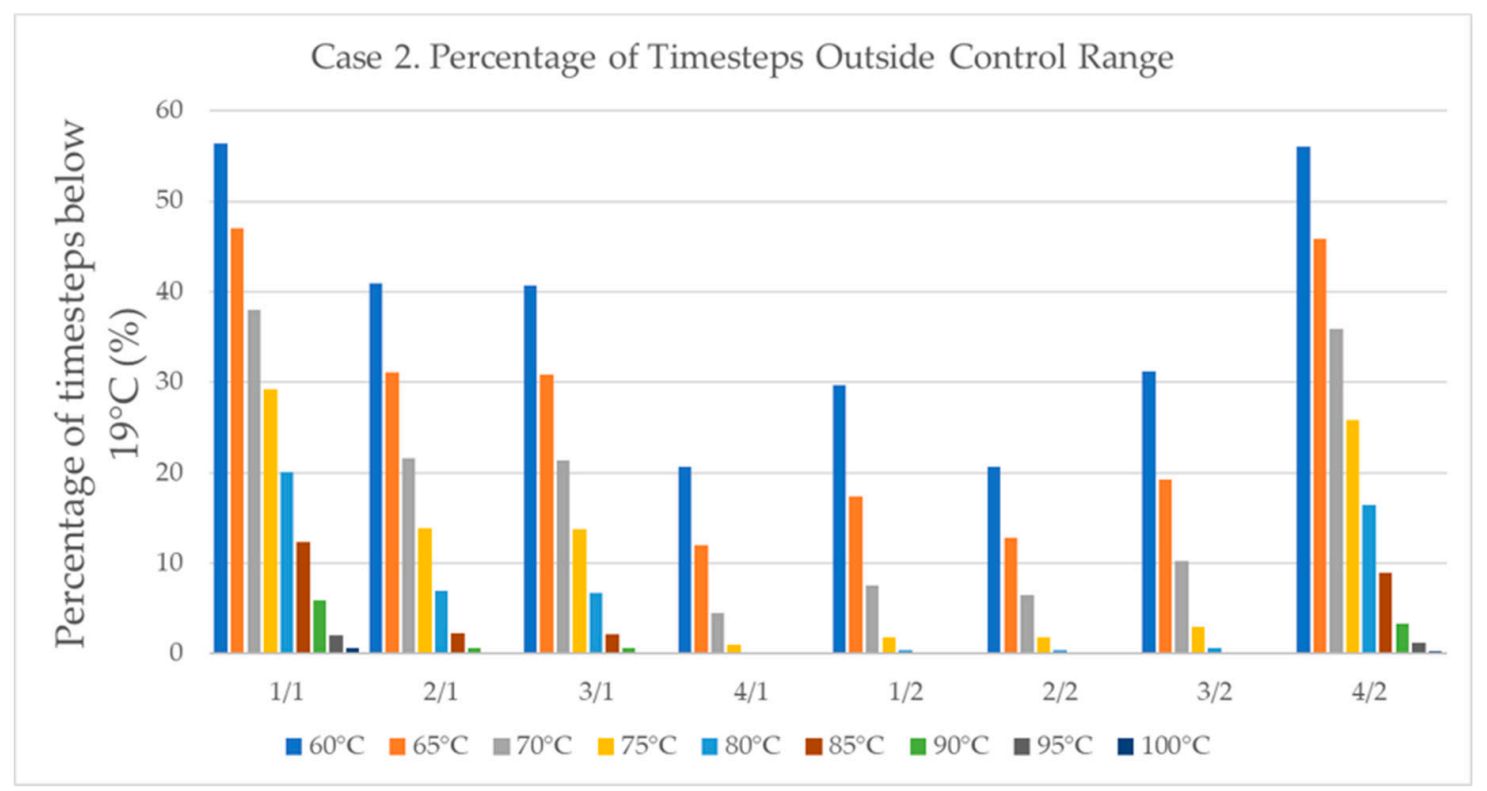

Figure 10. Case 2: no insulation and double glazing.

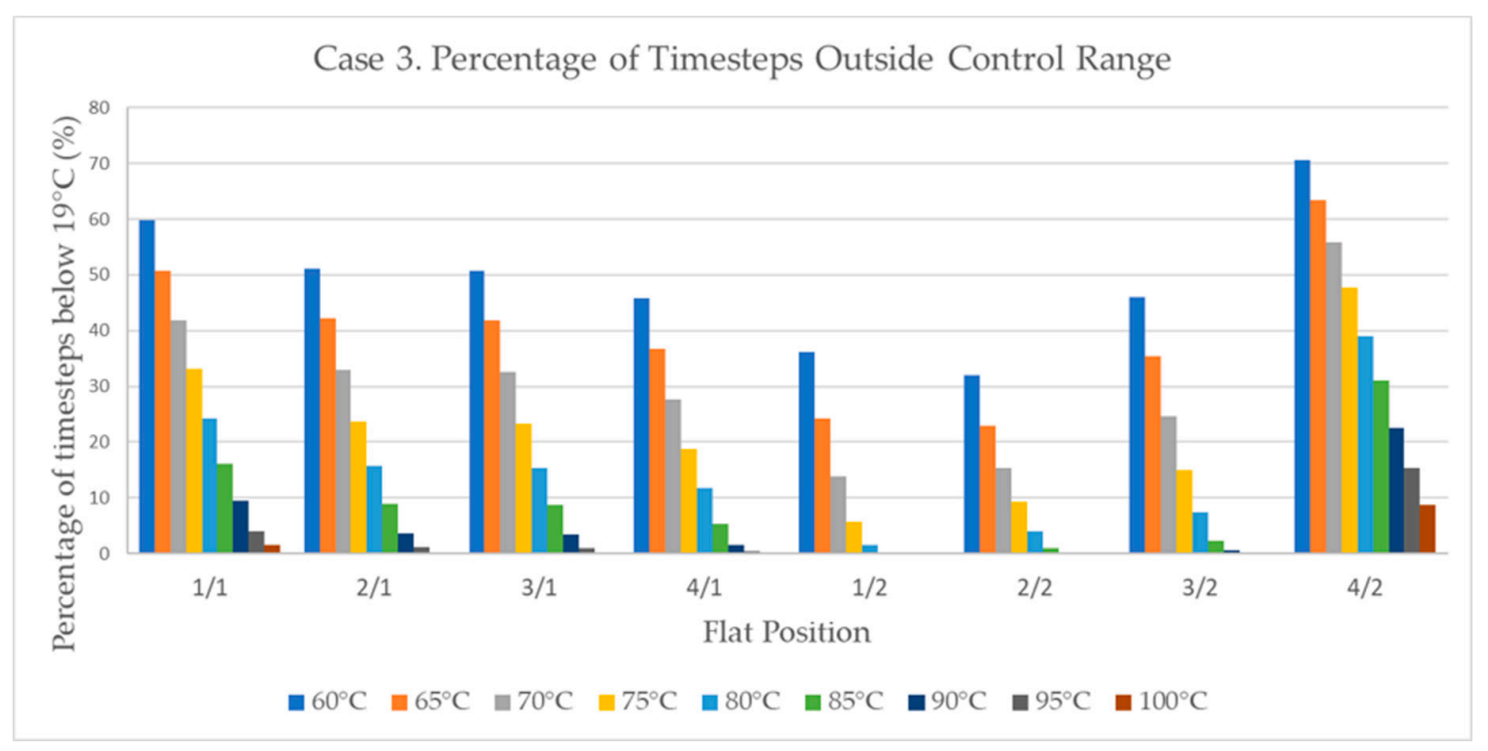

Figure 11. Case 3: insulation with single glazing. 


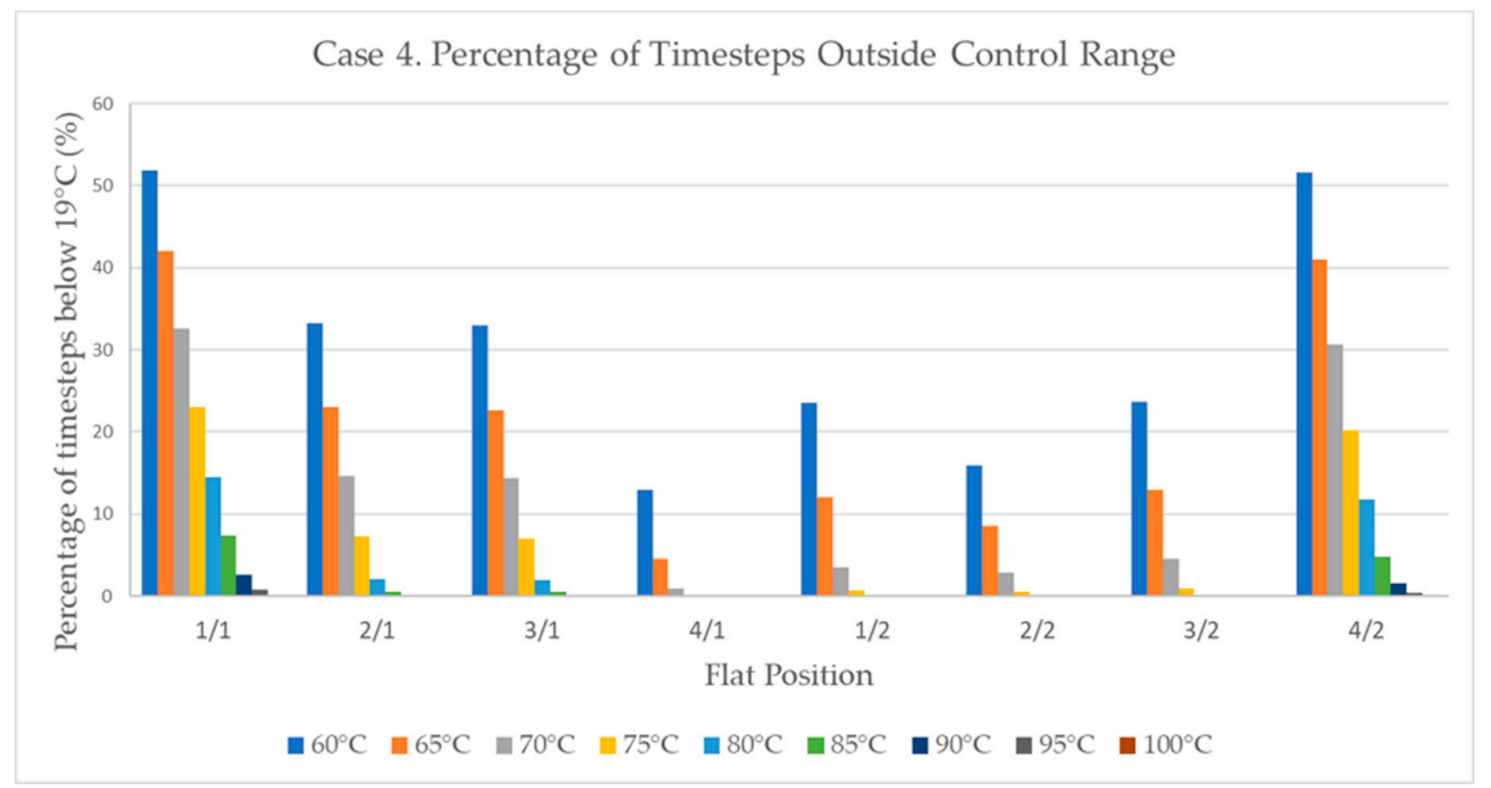

Figure 12. Case 4: insulation and double glazing.

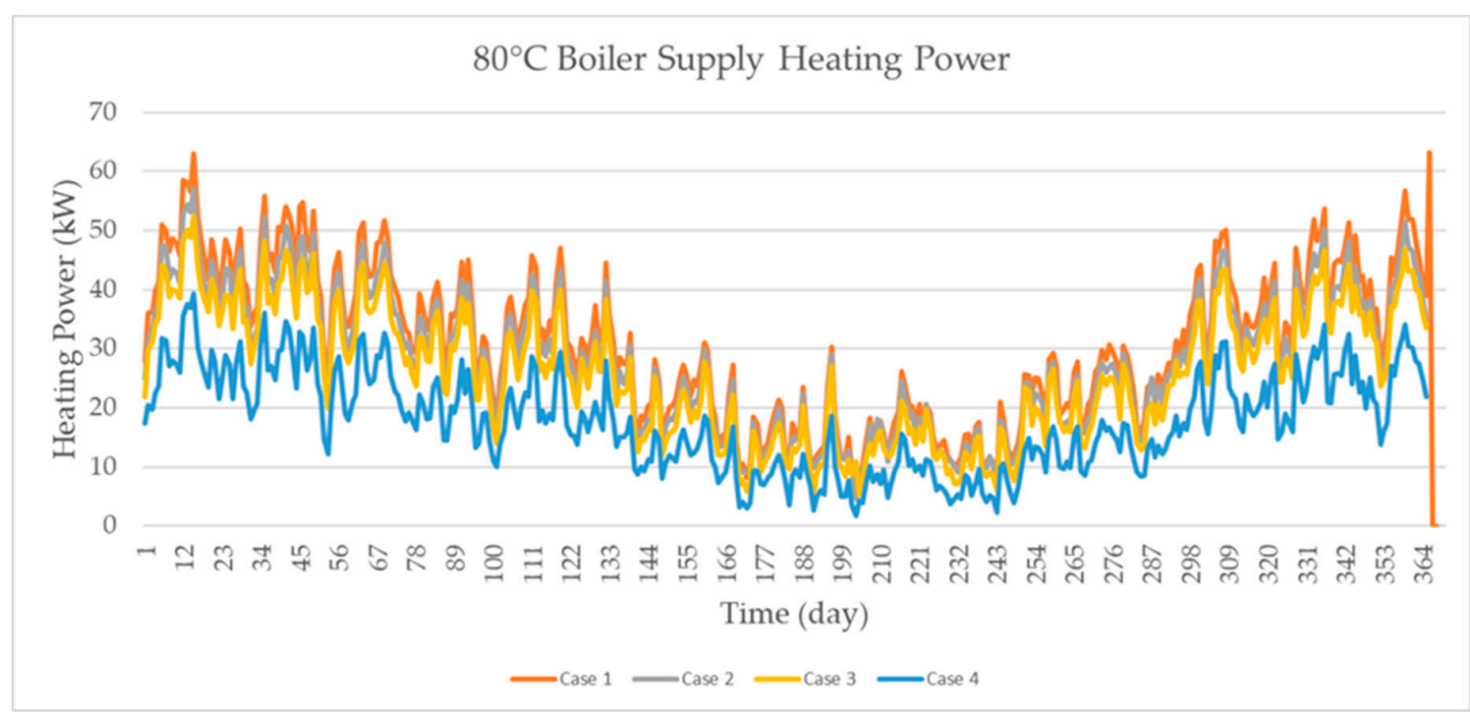

Figure 13. Case by case comparison of heating power demand at $80^{\circ} \mathrm{C}$.

\subsection{Carbon and Energy Savings}

The following tables show the computational results from modelling the gas boiler and heat pump energy usage at each case study. Table 5 shows the minimum achievable supply temperature chosen from Section 3.1, which is then used as the set point temperature for the modelled radiator supply. Table 6 shows the energy usage and saving when space heating is met only by the gas boiler for the base case of $80^{\circ} \mathrm{C}$ supply and for the chosen minimum. Table 7 shows the electricity and gas usage when the space heating is met by the river source heat pump and supplemented by gas boilers. Table 8 shows the equivalent carbon emissions for each case. All tables show results for the full block of flats. 
Table 5. Minimum supply temperature.

\begin{tabular}{cc}
\hline & Minimum Temperature \\
\hline Case 1 & 80 \\
Case 2 & 75 \\
Case 3 & 70 \\
Case 4 & 65 \\
\hline
\end{tabular}

Table 6. Gas boiler energy usage.

\begin{tabular}{cccc}
\hline \multicolumn{4}{c}{ Gas Boiler Energy Usage (MWh) } \\
\hline & $\mathbf{8 0}{ }^{\circ} \mathbf{C}$ & Minimum & Saving \\
\hline Case 1 & 271 & 271 & 0 \\
Case 2 & 249 & 234 & 15 \\
Case 3 & 227 & 219 & 8 \\
Case 4 & 154 & 150 & 4 \\
\hline
\end{tabular}

Table 7. Boiler and heat pump energy usage.

\begin{tabular}{|c|c|c|c|c|c|c|c|}
\hline \multicolumn{8}{|c|}{ Boiler and Heat Pump Energy Usage (MWh) } \\
\hline & \multicolumn{3}{|c|}{$80^{\circ} \mathrm{C}$ Supply Temperature } & \multicolumn{3}{|c|}{ Minimum Supply Temperature } & \multirow{2}{*}{ Saving } \\
\hline & Gas & Electricity & Total & Gas & Electricity & Total & \\
\hline Case 1 & 161 & 41 & 202 & 161 & 41 & 202 & 0 \\
\hline Case 2 & 145 & 37.3 & 182.3 & 133 & 41.7 & 174.7 & 7.6 \\
\hline Case 3 & 132 & 36 & 168 & 120 & 33 & 153 & 15 \\
\hline Case 4 & 75.4 & 32.5 & 107.9 & 51 & 36.8 & 87.8 & 20.1 \\
\hline
\end{tabular}

Table 8. Carbon emissions.

\begin{tabular}{ccccccc}
\hline \multicolumn{7}{c}{ Carbon Emissions (ton $\mathbf{C O}_{\mathbf{2 e}}$ ) } \\
\hline & \multicolumn{7}{c}{ Boiler } & \multicolumn{2}{c}{ Boiler and Heat Pump } & \multirow{2}{*}{ Saving } \\
\cline { 1 - 5 } & $\mathbf{8 0}{ }^{\circ} \mathbf{C}$ & Minimum & Saving & $\mathbf{8 0}^{\circ} \mathbf{C}$ & Minimum & \\
\hline Case 1 & 55.284 & 55.284 & 0 & 44.447 & 44.447 & 0 \\
Case 2 & 50.796 & 47.736 & 3.06 & 40.1359 & 38.9331 & 1.2028 \\
Case 3 & 46.308 & 44.676 & 1.632 & 37.116 & 33.819 & 3.297 \\
Case 4 & 31.416 & 30.6 & 0.816 & 24.5791 & 21.9 & 2.68 \\
\hline
\end{tabular}

The carbon emissions are based on the 2018 UK government conversion factor; $1 \mathrm{kWh}$ electricity is $0.283 \mathrm{~kg} \mathrm{CO}_{2 \mathrm{e}}$ and $1 \mathrm{kWh}$ natural gas is $0.204 \mathrm{~kg} \mathrm{CO}_{2 \mathrm{e}}$ [32].

\section{Discussion}

\subsection{Minimum Supply Temperature}

Figures 9-12 show the percentage of time steps with non-zero control signal that are below $19^{\circ} \mathrm{C}$. The minimum supply temperature is chosen as the point where the system can meet approximately $80 \%$ of the demand. The additional $20 \%$ needed can be met through thermal storage; these demand side management techniques are well documented elsewhere and therefore not considered here. For dwellings with no insulation or double glazing, this does not drop significantly until the supply temperature reaches $85{ }^{\circ} \mathrm{C}$ (a typical operating temperature of domestic radiators in the UK). For smaller district heating networks, the supply temperature is often kept below $80{ }^{\circ} \mathrm{C}$ to allow the use of polyethylene or polybutylene pipes in the distribution network; these pipes can only cope with a maximum of $90^{\circ} \mathrm{C}$ flow for short periods of time [25]. If thermal losses in the distribution system 
are considered, the temperature in the network will exceed $90^{\circ} \mathrm{C}$ for a significant duration, meaning pre-insulated steel carrier pipes will likely be needed. This greatly increases the project costs. An alternative is to operate the network at a lower temperature, in order to minimize capital cost through the use of polymer piping and supplement the conditioned stream from a pre-existing heating system within the dwelling. This would add costs only to the end user, which is not preferable. Given the financial significance of dwelling connections to the network economic model, it is not recommended to adopt this approach. It can therefore be concluded that, for dwellings that are poorly insulated with low quality windows, internal improvements must be made before connection to a district heating network becomes a viable option.

When the dwelling has been fitted with insulation but no double glazing, a $70{ }^{\circ} \mathrm{C}$ flow can, on average, meet the heating demand for over $80 \%$ of the year. On addition of double glazing, a $65^{\circ} \mathrm{C}$ flow can meet demand for around $79 \%$ of the year - largely similar to Case 3 with a $70{ }^{\circ} \mathrm{C}$ flow. Double glazing without insulation (Case 2) can only reach $78 \%$ of demand at $75{ }^{\circ} \mathrm{C}$. As is to be expected, the lowest supply temperature is achievable with double glazing and insulation. The addition of insulation offers a $36.1 \%$ improvement on air temperature maintenance, while the addition of double glazing offers only $28.3 \%$ improvement in Case 1. Case 4 (both insulation and double glazing) offers a $39 \%$ improvement in Case 1, but only a 3\% improvement in Case 2. It is therefore clear that, while the greatest improvement is with double glazing and insulation, the improvement by the double glazing is only marginal. The choice of double glazing should be considered based on the economic or carbon case.

\subsection{Water Source Heat Pump Supply}

In the sample year (2017), the average daily river Clyde temperature falls below $5{ }^{\circ} \mathrm{C}$ for $16 \%$ of the year. On these days, heating is supplied entirely from the gas boilers. For UK tenements, this necessitates a reliance on the gas boilers during this period; the boilers cannot be removed from the dwellings. While this is common in the UK, the dependence on gas can be phased out with improved thermal storage and demand side management.

For Case 1 (no insulation, single glazing), the supply temperature could not be reduced and so remained at $80^{\circ} \mathrm{C}$. When the water source heat pump is used with the gas boiler, a $25 \%$ reduction in energy and $20 \%$ carbon saving can be achieved.

From Table 7, it is clear that a reduction in total energy usage does not relate to a linear reduction in electricity to the heat pump. This is because the return temperature from the radiators is typically above the heating set point of the heat pump $\left(60^{\circ} \mathrm{C}\right)$, meaning that the heat pump is used to heat the radiator loop initially, but not continuously, during heating.

\section{Conclusions}

The UK faces challenges to decarbonize the domestic heating sector, but has few choices to do this. The best options will offer significant carbon benefits and be competitively priced to the current heating market. This work has presented a dynamic transient system simulation tool model of a typical tenement flat in the UK, one of the most common dwelling types. From this work, the following conclusions can be drawn:

The minimum supply temperature of domestic radiator systems, and therefore district heating schemes supplying tenement buildings, is strongly dependent on the building condition. Wall insulation can be difficult to install in solid wall tenement blocks but can yield a $16 \%$ energy saving on space heating per year, without lowering the supply temperature. Double glazing had less of an impact in this study but may be more significant in buildings with a greater window to wall ratio.

Tenement blocks in poor condition are unlikely to be able to connect to a district heating scheme, due to the high supply temperatures giving rise to a significant cost of carrier pipes. 
In cases where no supply temperature reduction is feasible, energy and carbon savings can still be made from integrating low carbon technology. In Case 1 with heat pump supply at an $80^{\circ} \mathrm{C}$ set point, energy consumption was reduced by $25 \%$ and the carbon footprint by $20 \%$.

When building conditions permit, supply temperature can be reduced to around $65{ }^{\circ} \mathrm{C}$ and could yield almost a $70 \%$ reduction in space heating.

While there are currently no restrictions in Scotland on river heat abstraction, this is heavily dependent on the local laws.

\section{Future Work}

This work is presented as the start of a conversation around district heating connections for traditional housing in the UK. For this work to progress:

A substantial building condition survey of UK housing stock is needed to afford a better appreciation of the potential of low temperature heating.

Greater government incentive must be offered for privately owned dwellings to decarbonize heating.

Further minimum supply temperature studies of other dwelling types are needed, potentially offering a tool for developers to easily assess the minimum feasible supply temperature for retrofitted projects.

Author Contributions: Conceptualization, M.A.M., N.M.B. and Z.Y.; methodology, M.A.M.; investigation, M.A.M.; writing—original draft preparation, M.A.M.; writing—review and editing, M.A.M., N.M.B. and Z.Y.; supervision, N.M.B. and Z.Y.; funding acquisition, N.M.B. and Z.Y.

Funding: This research was funded by the National Productivity and Investment Fund EPSRC Doctoral Scheme (EP/R512266/1), Clyde Gateway and received support from the EPSRC "Combi-Gen" project (EP/P028829/1) and the EU H2020 LCE "DESTRESS" project (EC-691728). The research was also funded by the Newton Fund (EP/R003122/1) and research fund EP/N020472/1.

Acknowledgments: We would like to thank SEPA for supply the environmental data used in modelling. We would also like to thank Tim McDowell and David Bradley from TESS for the support received during the modelling process. Finally, we would like to thank the Glasgow City Archives for the use of building plans.

Conflicts of Interest: The authors declare no conflict of interest.

\section{References}

1. Digest of United Kingdom Energy Statistics. Department for Business, Energy and Industrial Strategy, 2018. Available online: https://www.gov.uk/government/collections/digest-of-uk-energy-statistics-dukes (accessed on 5 July 2019).

2. Heat Policy Statement; Scottish Government: Edinburgh, UK, 2015. Available online: https://www.gov.scot/binaries/content/documents/govscot/publications/publication/2015/06/heat-policystatement-towards-decarbonising-heat-maximising-opportunities-scotland/documents/00478997-pdf/ 00478997-pdf/govscot\%3Adocument (accessed on 5 July 2019).

3. Clarkson, A.; Laird, E.; Lloyd, D. Scottish House Condition Survey: 2017 Key Findings. 2018. Available online: https://www.gov.scot/publications/scottish-house-condition-survey-2017-key-findings/ (accessed on 5 July 2019).

4. Haapio, A.; Viitaniemi, P. A critical review of building environmental assessment tools. Environ. Impact Assess. Rev. 2008, 28, 469-482. [CrossRef]

5. Cetiner, I.; Edis, E. An environmental and economic sustainability assessment method for the retrofitting of residential buildings. Energy. Build. 2014, 74, 132-140. [CrossRef]

6. Brand, M.; Svendsen, S. Renewable-based low-temperature district heating for existing buildings in various stages of refurbishment. Energy 2013, 62, 311-319. [CrossRef]

7. Vallios, I.; Tsoutsos, T.; Papadakis, G. Design of biomass district heating systems. Biomass Bioenergy 2009, 33, 659-678. [CrossRef]

8. Østergaard, D.S.; Svendsen, S. Replacing critical radiators to increase the potential to use low-temperature district heating - A case study of 4 Danish single-family houses from the 1930s. Energy 2016, 110, 75-84. [CrossRef] 
9. Harrestrup, M.; Svendsen, S. Changes in heat load profile of typical Danish multi-storey buildings when energy-renovated and supplied with low-temperature district heating. Int. J. Sustain. Energy 2015, 34, 232-247. [CrossRef]

10. Li, H.; Nord, N. Transition to the 4th generation district heating - possibilities, bottlenecks, and challenges. Energy Procedia 2018, 149, 483-498. [CrossRef]

11. Wang, Q.; Holmberg, S. Combined Retrofitting with Low Temperature Heating and Ventilation Energy Savings. Energy Procedia 2015, 78, 1081-1086. [CrossRef]

12. Burzynski, R.; Crane, M.; Yao, R.; Becerra, V.M. Space heating and hot water demand analysis of dwellings connected to district heating scheme in UK. J. Cent. South Univ. 2012, 19, 1629-1638. [CrossRef]

13. Allard, I.; Olofsson, T.; Nair, G. Energy evaluation of residential buildings: Performance gap analysis incorporating uncertainties in the evaluation methods. Build. Simul. 2018, 11, 725-737. [CrossRef]

14. Fedoruk, L.E.; Cole, R.J.; Robinson, J.B.; Cayuela, A. Learning from failure: Understanding the anticipated-achieved building energy performance gap. Build. Res. Inf. 2015, 43, 750-763. [CrossRef]

15. Johnston, D.; Miles-Shenton, D.; Farmer, D. Quantifying the domestic building fabric 'performance gap'. Build. Serv. Eng. Res. Technol. 2015, 36, 614-627. [CrossRef]

16. McElroy, D.J.; Rosenow, J. Policy implications for the performance gap of low-carbon building technologies. Buil. Res. Inf. 2019, 47, 611-623. [CrossRef]

17. Zou, P.X.W.; Xu, X.; Sanjayan, J.; Wang, J. Review of 10 years research on building energy performance gap: Life-cycle and stakeholder perspectives. Energy Build. 2018, 178, 165-181. [CrossRef]

18. Ovchinnikov, P.; Borodinecs, A.; Strelets, K. Utilization potential of low temperature hydronic space heating systems: A comparative review. Build. Environ. 2017, 112, 88-98. [CrossRef]

19. Ovchinnikov, P.; Borodinecs, A.; Millers, R. Utilization potential of low temperature hydronic space heating systems in Russia. J. Build. Eng. 2017, 13, 1-10. [CrossRef]

20. Peeters, L.; Van der Veken, J.; Hens, H.; Helsen, L.; D’haeseleer, W. Control of heating systems in residential buildings: Current practice. Energy Build. 2008, 40, 1446-1455. [CrossRef]

21. Liao, Z.; Swainson, M.; Dexter, A.L. On the control of heating systems in the UK. Build. Environ. 2005, 40, 343-351. [CrossRef]

22. Solar Energy Laboratory. TRNSYS, a Transient Simulation Program; Solar Energy Laboratory: Madison, WI, USA, 1975.

23. Solar Energy Laboratory. TRNSYS18: Volume 1 Getting Started; Solar Energy Laboratory: Madison, WI, USA, 2017.

24. Baker, P. U-Values and Traditional Buildings; Historic Scotland: Edinburgh, UK, 2011; Available online: https://www.historicenvironment.scot/archives-and-research/publications/publication/ ?publicationId=16d0f7f7-44c4-4670-a96b-a59400bcdc91 (accessed on 5 July 2019).

25. Wiltshire, R.; Williams, J.; Woods, P. A Technical Guide to District Heating; BRE Publications: Watford, UK, 2014; Available online: https://www.brebookshop.com/samples/327451.pdf (accessed on 5 July 2019).

26. Dansk Standard (DS). Calculation of heat loss from buildings; DS 418:2011; Dansk Standard (DS): København, Denmark, 2011.

27. Solar Energy Laboratory. TRNSYS18 Volume 5: Multizone Building Modelling with Type56 and TRNBuild; Solar Energy Laboratory: Madison, WI, USA, 2017.

28. Stephenson, D.G.; Mitalas, G.P. Calculation of heat conduction transfer functions for multi-layer slabs. ASHRAE Trans. 1971, 77, 117-126.

29. Mitalas, G.P.; Arseneault, J.G. Fortran IV Program to Calculate Z-Transfer Functions for the Calculation of Transient Heat Transfer Through Walls and Roofs. 1971. Available online: https://www.ibpsa.us/sites/default/files/publications/B10_34_1972_Jun_Fortran\%20IV\%20Program\% 20 to $\% 20$ Calculate $\% 20 \mathrm{z}$-Transfer $\% 20$ Funtions $\% 20$ for $\% 20$ the $\% 20$ Calculation $\% 20$ of $\% 20$ Transient $\% 20$ Heat $\%$ 20Transfer\%20through\%20Walls\%20and\%20Roofs_National\%20Research\%20Council\%20Canada.pdf (accessed on 5 July 2019).

30. Palmer, J.; Cooper, I. United Kingdom Housing Energy Fact Fil; Research Consultants and Cambridge Energy: Cambridge, UK, 2013; Available online: http://www.carltd.com/sites/carwebsite/files/Housing\%20Energy\% 20Fact\%20File\%202012.pdf (accessed on 5 July 2019). 
31. The Building (Scotland) Regulations 2004. Available online: http://www.legislation.gov.uk/ssi/2004/406/ contents/made (accessed on 5 July 2019).

32. Total greenhouse gas emission trends and projections. Available online: https://www.eea.europa.eu/dataand-maps/indicators/greenhouse-gas-emission-trends-6/assessment-1 (accessed on 5 July 2019).

(C) 2019 by the authors. Licensee MDPI, Basel, Switzerland. This article is an open access article distributed under the terms and conditions of the Creative Commons Attribution (CC BY) license (http://creativecommons.org/licenses/by/4.0/). 